Tkachuk S. S., Tkachuk O. V., Povar M. A., Yasinska O. V., Denysenko O. I. State of proteolytic and fibrinolytic processes in the brain of rats with experimental diabetes mellitus complicated by cerebrovascular accident in the basin of the carotid arteries. $\begin{array}{llllll}\text { Journal of Education, Health and Sport. 2021;11(07):288-297. } & \text { eISSN }\end{array}$ http://dx.doi.org/10.12775/JEHS.2021.11.07.027 https://apcz.umk.pl/JEHS/article/view/JEHS.2021.11.07.027 https://zenodo.org/record/5567223

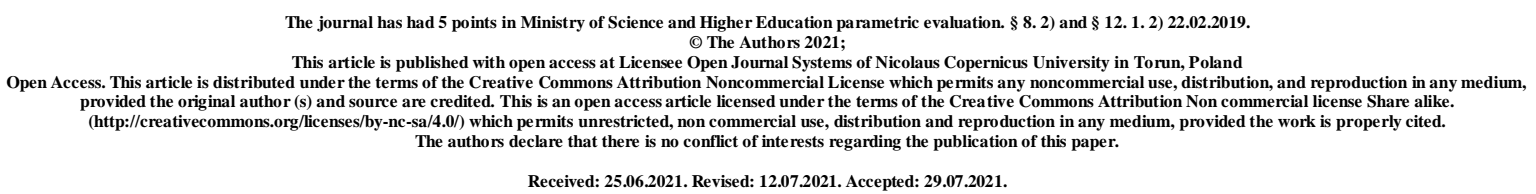

\title{
STATE OF PROTEOLYTIC AND FIBRINOLYTIC PROCESSES IN THE BRAIN OF RATS WITH EXPERIMENTAL DIABETES MELLITUS COMPLICATED BY CEREBROVASCULAR ACCIDENT IN THE BASIN OF THE CAROTID ARTERIES
}

\author{
S. S. Tkachuk, O. V. Tkachuk, M. A. Povar, O. V. Yasinska, O. I. Denysenko
}

\section{Bukovinian State Medical University, Chernivtsi, Ukraine}

\section{Abstract}

Introduction. The imbalance in the protease-antiprotease system is an integral part of the pathogenesis of acute disorder of cerebrovascular circulation and diabetes mellitus (DM), but its manifestations in the complication of diabetes by ischemia-reperfusion of the brain have not been investigated yet.

The objective of the work - to study the dynamics of carotid ischemia-reperfusion effect on the proteo- and fibrinolytic activity in brain structures of rats with experimental DM.

Rats with the four-month streptozotocin DM were modeled bilateral carotene ischemia during 20 minutes. In homogenates of brain structures, indicators of proteo- fibrinolytic activity were determined after 1 hour from the beginning of reperfusion and during the 12th day of the post-ischemic period. In the absence of DM, the proteolytic activity of all or individual indicators il increased in both periods of the post-ischemic period in the cortex of the frontal and occipital lobes, the fields of hippocampus CA2 and CA3, and during the 12th day in the field CA1.

Results. In rats with diabetes, in all brain structures, there are no changes in the lysis of azo-albumin and azo-casein in both terms of observation and lysis of collagen 
progressively decreases. In rats without DM in the cortex of the studied particles, fields of the hippocampus CA1 and CA2, all or separate indices of fibrinolytic activity are increased in both periods of the post-ischemic period, in the field CA3 - all indices at the 12th day. In the presence of diabetes in the cortex of both studied lobes and the field CA1, the fibrinolytic activity decreases in the late post-ischemic period, in the fields of CA2 and CA3 - during both observation periods.

Conclusion. In the brain structures under investigation at both time intervals, the DM eliminates the reaction of low and high molecular weight proteins to the ischemia-reperfusion and suppresses fibrinolytic activity.

Key words: diabetes mellitus; ischemia-reperfusion of the brain; proteolysis; fibrinolysis.

The pathogenesis of ischemic-reperfusion damage of the brain is polydromic and is realized with the participation of specific and nonspecific mechanisms. The latter is an imbalance in the system of protease-antiprotease, which occurs in the early stages of ischemia and is the part of the mechanisms of development of excitotoxicity [7] and continues during later periods, participating in violations of the permeability of the blood-brain barrier and the occurrence of inflammatory processes [14].

On the other hand, such an imbalance arises in conditions of both insulin-deficiency and insulin resistance, that is, it accompanies the course of type I and type II diabetes mellitus [8] and occurs due to activation of caspase-3 and ubiquitinproteasome system [4].

The growth of pro-sclerotic cytokines' production in diabetes mellitus with and the violation of the relationship between activators and proteolytic inhibitors increases the fibrosis of the extracellular matrix [5, 10, 17], and the resistance to proteases of glycosylated structural proteins contributes the the accumulation of modified proteins $[11,12,16]$. According to the literature, the normalization of proteasome activity may have a protective effect on the development of diabetic complications [13].

Consequently, both diabetes mellitus and ischemia-reperfusion of the brain have in their pathogenesis a violation of the proteolytic activity (and, as its separate species fibrinolytic), however, in combination of these pathological states proteoand fibrinolytic parameters in some brain structures were not investigated. 
The objective and tasks: to study the dynamics of the effect of bilateral carotid ischemia-reperfusion onto the parameters of proteo- and fibrinolytic activity in the brain structures of rats with streptozotocin-induced diabetes mellitus.

Materials and methods of the study. Simulation of DM was performed by single intra-peritoneal administration of streptozotocin to the two-month non-linear laboratory male rats (Sigma, USA, $60 \mathrm{mg} / \mathrm{kg}$ of body weight) [3]. Four months later, groups of rats of identical age without and with diabetes were formed, which under the calypsol anesthesia (70 $\mathrm{mg} / \mathrm{kg}$ of body weight) were performed bilateral clipping of the common carotid arteries [1] for 20 minutes followed by reperfusion lasting for one hour and 12 days.

The level of glycemia was determined by the glucose-oxidase method. All studies in animals with diabetes were carried out in their level of glycemia higher than $10 \mathrm{mmol} / \mathrm{l}$. Animals were withdrawn from the experiment by decapitation under anesthesia (calypsol, 70 $\mathrm{mg} / \mathrm{kg}$ of body weight). The brain was taken into the cold and fixed in liquid nitrogen; the studied structures were identified using the coordinates of the stereotactic atlas [18]. The parameters of tissue fibrinolytic (total (TFA), non-enzymatic (NFA) and enzymatic (EFA)) and proteolytic (lysis of low-, high-molecular-weight proteins, and collagen) activity [2] using reagents of Simko Ltd, Ukraine, were determined in the homogenates of th cortex of the frontal and occipital lobes (CFL and COL), the fields of the hippocampus CA1, CA2, and CA3.

The research results were processed using the application package "Statistica" ("Statsoft", USA). According to the Shapiro-Wilk test, the comparison groups had a normal distribution. The statistical significance of the differences was estimated by the Student's tcriterion for the independent choices. The data is represented in the form of arithmetic mean and standard deviation.

Results and discussion. According to the data represented in Table 1, in animals without DM in the cortex of both lobes after 20-minute carotid ischemia with one-hour reperfusion lysis rates of high molecular weight proteins and collagen increased; at the 12th day of the ischemic-reperfusion period - the lysis of low-, highmolecular-weight proteins and collagen increased. The dynamics in the CFL was in higher indices of lysis of low molecular weight proteins and collagen at the 12th day, and in the COL - of all of the studied indicators.

In rats with diabetes, in both of the investigated lobes of the cortex, there were lower lysis rates of low molecular weight proteins than in animals without this pathology, and in the COL - also higher azocoll lysis. In the early and late postischemic periods in both lobes of the 
rats' cortex, the lysis of collagen in relation to the indicator in animals with diabetes without ischemia-reperfusion of the brain was reduced, and during the 12th day - there was the decrease of this index and its values in the early terms.

Table 1

Effect of ischemia-reperfusion onto proteolysis indices in the cortex of forehead and nape lobes of male rats in conditions of diabetes mellitus $(M \pm m, n=11)$

\begin{tabular}{|c|c|c|c|}
\hline Observation group & $\begin{array}{c}\text { Lysis of low } \\
\text { molecular } \\
\text { weight proteins } \\
(\mu \mathrm{g} \\
\text { azoalbumin } / \mathrm{g} \\
\text { tissue per hour) }\end{array}$ & $\begin{array}{l}\text { Lysis of high } \\
\text { molecular weight } \\
\text { proteins }(\mu \mathrm{g} \\
\text { azocasein/g tissue } \\
\text { per hour) }\end{array}$ & $\begin{array}{c}\text { Lysis of } \\
\text { collagen }(\mu \mathrm{g} \\
\text { azocoll/g tissue } \\
\text { per hour) }\end{array}$ \\
\hline \multicolumn{4}{|c|}{ Cortex of frontal lobe } \\
\hline \begin{tabular}{|l|} 
Control \\
\end{tabular} & $129.95 \pm 3.82$ & $92.32 \pm 2.77$ & $5.76 \pm 0.15$ \\
\hline Ischemia-reperfusion, $20 \mathrm{~min} / 1$ hour & $127.69 \pm 2.71$ & $111.76 \pm 3.21 *$ & $6.44 \pm 0.15^{*}$ \\
\hline Ischemia-reperfusion 12 days & $149.50 \pm 3.01^{* \wedge}$ & $112.34 \pm 1.98^{*}$ & $7.59 \pm 0.22^{* \wedge}$ \\
\hline Diabetes & $105.09 \pm 7.31 *$ & $97.74 \pm 5.02$ & $7.01 \pm 0.61$ \\
\hline $\begin{array}{l}\text { Diabetes and ischemia-reperfusion } 20 \\
\text { min/1 hour }\end{array}$ & $105.77 \pm 3.09$ & $96.84 \pm 4.29$ & $4.41 \pm 0.42 \#$ \\
\hline $\begin{array}{l}\text { Diabetes and ischemia-reperfusion } 12 \\
\text { days }\end{array}$ & $111.45 \pm 7.52$ & $102.06 \pm 6.31$ & $3.29 \pm 0.29 \# \&$ \\
\hline \multicolumn{4}{|c|}{ Cortex of occipital lobe } \\
\hline Control & $124.30 \pm 2.47$ & $85.43 \pm 2.41$ & $4.98 \pm 0.18$ \\
\hline Ischemia-reperfusion, $20 \mathrm{~min} / 1$ hour & $127.69 \pm 4.54$ & $115.26 \pm 3.37 *$ & $6.01 \pm 0.26^{*}$ \\
\hline Ischemia-reperfusion 12 days & $139.86 \pm 3.32^{* \wedge}$ & $127.31 \pm 4.29^{* \wedge}$ & $6.98 \pm 0.21^{* \wedge}$ \\
\hline Diabetes & $100.46 \pm 6.34 *$ & $95.71 \pm 6.26$ & $6.61 \pm 0.56^{*}$ \\
\hline $\begin{array}{l}\text { Diabetes and ischemia-reperfusion } 20 \\
\text { min/1 hour }\end{array}$ & $107.01 \pm 5.84$ & $98.20 \pm 5.08$ & $5.01 \pm 0.29 \#$ \\
\hline $\begin{array}{l}\text { Diabetes and ischemia-reperfusion } 12 \\
\text { days }\end{array}$ & $98.65 \pm 4.98$ & $102.38 \pm 5.08$ & $4.15 \pm 0.21 \# \&$ \\
\hline
\end{tabular}

Notes. In all tables of the article, the reliability of a difference is compared with: * control; ${ }^{\wedge}$ - ischemia-reperfusion ( $20 \mathrm{~min} / 1 \mathrm{~h}$ ) in control animals; \# -diabetes; $\boldsymbol{\&}$ - ischemia-reperfusion $(20 \mathrm{~min} / 1 \mathrm{~h})$ in animals with diabetes

Data on the state of tissue proteolytic activity in the fields of the hippocampus of rats of various experimental groups are represented in Table 2. In the field of the hippocampus CA1 of animals without diabetes, in relation to the indicators in animals of the control group, there was the decreased lysis of low molecular weight proteins in both terms of observation. In addition, at the 12th day in this structure there was also an increased lysis of highmolecular proteins and collagen. In the fields of CA2 and CA3, in the early post-ischemic period, there was an increase in the lysis of high-molecular proteins and collagen relative to 
these indicators in the control animals; at the 12th day of the ischemic-reperfusion period, the values of these indicators remained elevated (in the field of CA2 - at the level of the previous term, in the field CA3 - increased as for their values in the early term). Thus, the response of the studied parameters onto the ischemia-reperfusion in the fields of CA2 and CA3 is similar, but in the field CA1 differs, which is consistent with existing ideas about the selective sensitivity of the field CA1 to the ischemia-reperfusion [9].

Table 2

Effect of ischemia-reperfusion onto proteolysis indices in different fields of hippocampus of male rats in conditions of diabetes mellitus $(M \pm m, n=11)$

\begin{tabular}{|c|c|c|c|}
\hline Observation group & \begin{tabular}{|c|} 
Lysis of low \\
molecular weight \\
proteins $(\mu \mathrm{g}$ \\
azoalbumin/g tissue \\
per hour)
\end{tabular} & $\begin{array}{l}\text { Lysis of high } \\
\text { molecular } \\
\text { weight proteins } \\
\text { ( } \mu \text { g azocasein/g } \\
\text { tissue per hour) }\end{array}$ & $\begin{array}{c}\text { Lysis of } \\
\text { collagen ( } \mu \mathrm{g} \\
\text { azocoll/g tissue } \\
\text { per hour })\end{array}$ \\
\hline \multicolumn{4}{|c|}{ Field of hippocampus CA1 } \\
\hline Control & $143.51 \pm 3.76$ & $107.46 \pm 2.87$ & $6.85 \pm 0.21$ \\
\hline Ischemia-reperfusion, $20 \mathrm{~min} / 1$ hour & $118.65 \pm 5.35^{*}$ & $115.26 \pm 4.06$ & $7.43 \pm 0.35$ \\
\hline Ischemia-reperfusion 12 days & $121.05 \pm 6.28 *$ & $123.13 \pm 3.78^{*}$ & $7.84 \pm 0.28 *$ \\
\hline Diabetes & $117.52 \pm 9.35^{*}$ & $118.65 \pm 9.16$ & $8.29 \pm 0.76$ \\
\hline $\begin{array}{l}\text { Diabetes and ischemia-reperfusion } 20 \\
\mathrm{~min} / 1 \text { hour }\end{array}$ & $115.26 \pm 6.35$ & $107.69 \pm 6.82$ & $5.28 \pm 0.49 \#$ \\
\hline $\begin{array}{l}\text { Diabetes and ischemia-reperfusion } 12 \\
\text { days }\end{array}$ & $106.31 \pm 6.35$ & $99.35 \pm 6.82$ & $4.98 \pm 0.49 \#$ \\
\hline \multicolumn{4}{|c|}{ Field of hippocampus CA2 } \\
\hline Control & $144.64 \pm 3.79$ & $115.26 \pm 2.73$ & $6.45 \pm 0.13$ \\
\hline Ischemia-reperfusion, $20 \mathrm{~min} / 1$ hour & $150.29 \pm 5.01$ & $143.51 \pm 5.08^{*}$ & $8.95 \pm 0.41 *$ \\
\hline Ischemia-reperfusion 12 days & $149.31 \pm 3.35$ & $148.65 \pm 6.55^{*}$ & $10.01 \pm 0.57 *$ \\
\hline Diabetes & $129.82 \pm 7.24$ & $131.08 \pm 6.02 *$ & $8.77 \pm 0.61 *$ \\
\hline $\begin{array}{l}\text { Diabetes and ischemia-reperfusion } 20 \\
\mathrm{~min} / 1 \text { hour }\end{array}$ & $133.34 \pm 7.02$ & $124.30 \pm 5.71$ & $6.33 \pm 0.57 \#$ \\
\hline $\begin{array}{l}\text { Diabetes and ischemia-reperfusion } 12 \\
\text { days }\end{array}$ & $141.27 \pm 7.02$ & $141.30 \pm 6.58$ & $5.72 \pm 0.41 \#$ \\
\hline \multicolumn{4}{|c|}{$\begin{aligned} \text { Field of hippocampus CA3 } \\
\end{aligned}$} \\
\hline Control & $137.86 \pm 4.76$ & $104.86 \pm 2.15$ & $5.49 \pm 0.14$ \\
\hline Ischemia-reperfusion, $20 \mathrm{~min} / 1$ hour & $127.69 \pm 5.43$ & $123.17 \pm 3.93 *$ & $7.51 \pm 0.12 *$ \\
\hline Ischemia-reperfusion 12 days & $131.54 \pm 6.09$ & $135.78 \pm 4.05^{* \wedge}$ & $8.16 \pm 0.12^{* \wedge}$ \\
\hline Diabetes & $126.56 \pm 6.71$ & $123.17 \pm 5.91 *$ & $8.28 \pm 0.72 *$ \\
\hline $\begin{array}{l}\text { Diabetes and ischemia-reperfusion } 20 \\
\mathrm{~min} / 1 \text { hour }\end{array}$ & $120.91 \pm 5.65$ & $113.25 \pm 5.52$ & $5.69 \pm 0.52 \#$ \\
\hline $\begin{array}{l}\text { Diabetes and ischemia-reperfusion } 12 \\
\text { days }\end{array}$ & $118.06 \pm 6.29$ & $119.67 \pm 7.21$ & $3.02 \pm 0.28 \# \&$ \\
\hline
\end{tabular}

These parameters were characterized by structural sensitivity to the DM: as to the values in the animals with the absence of this pathology in the field CA1 of animals with 
diabetes the lower lysis index of low molecular weight proteins was detected, and in the fields $\mathrm{CA} 2$ and CA3 - the higher values of lysis of high-molecular proteins and collagen were determined. It is characteristically, that in animals with DM in all studied fields of hippocampus and cortex of both lobes the reaction in both periods of the ischemic-reperfusion period consisted of a progressive decrease in lysis of collagen compared to these indices in diabetes, uncomplicated by cerebrovascular disruption. Such stability of the reaction allows us to think of the marker value of this index for the ischemicreperfusion injuries of the brain in DM.

The study of the response of fibrinolytic activity indices to these experimental interventions showed that in the rats without DM after the end of the early and late ischemicreperfusion periods in the CFL and the COL, the TFA, NFA and EFA values were higher than those of the control animals (Table 3). In addition, during the 12th day of observation, the values of TFA and EFA significantly exceeded those of the previous observation period.

Table 3

Effect of ischemia-reperfusion onto proteolysis indices in the cortex of frontal and occipital lobes of male rats in conditions of diabetes mellitus $(M \pm m, n=11)$

\begin{tabular}{|c|c|c|c|}
\hline Observation group & \begin{tabular}{|c|} 
Lysis of low \\
molecular weight \\
proteins $(\mu \mathrm{g}$ \\
azoalbumin/g tissue \\
per hour)
\end{tabular} & $\begin{array}{l}\text { Lysis of high } \\
\text { molecular } \\
\text { weight proteins } \\
\text { ( } \mu \text { g azocasein/g } \\
\text { tissue per hour) }\end{array}$ & $\begin{array}{c}\text { Lysis of } \\
\text { collagen }(\mu \mathrm{g} \\
\text { azocoll/g tissue } \\
\text { per hour })\end{array}$ \\
\hline \multicolumn{4}{|c|}{ Cortex of frontal lobe } \\
\hline Control & $41.58 \pm 1.16$ & $21.84 \pm 0.49$ & $19.74 \pm 0.79$ \\
\hline Ischemia-reperfusion, $20 \mathrm{~min} / 1$ hour & $58.19 \pm 1.64 *$ & $28.36 \pm 1.23 *$ & $29.83 \pm 1.13 *$ \\
\hline Ischemia-reperfusion 12 days & $63.76 \pm 1.08^{* \wedge}$ & $29.67 \pm 1.23 *$ & $34.09 \pm 1.02^{* \wedge}$ \\
\hline Diabetes & $54.08 \pm 3.96 *$ & $25.81 \pm 2.03$ & $28.27 \pm 1.63 *$ \\
\hline $\begin{array}{l}\text { Diabetes and ischemia-reperfusion } 20 \\
\mathrm{~min} / 1 \text { hour }\end{array}$ & $54.80 \pm 2.08$ & $28.62 \pm 1.34$ & $26.18 \pm 0.74$ \\
\hline $\begin{array}{l}\text { Diabetes and ischemia-reperfusion } 12 \\
\text { days }\end{array}$ & $39.40 \pm 2.16 \# \&$ & $19.64 \pm 1.78 \# \&$ & $19.76 \pm 0.68 \# \&$ \\
\hline \multicolumn{4}{|c|}{$\begin{aligned} \text { Cortex of occipital lobe } \\
\end{aligned}$} \\
\hline Control & $34.29 \pm 0.60$ & $18.69 \pm 0.53$ & $15.60 \pm 0.45$ \\
\hline Ischemia-reperfusion, $20 \mathrm{~min} / 1$ hour & $52.14 \pm 0.73 *$ & $25.69 \pm 0.67 *$ & $26.44 \pm 0.64 *$ \\
\hline Ischemia-reperfusion 12 days & $54.78 \pm 0.58^{* \wedge}$ & $25.06 \pm 0.34 *$ & $29.72 \pm 0.48^{* \wedge}$ \\
\hline Diabetes & $50.68 \pm 3.22 *$ & $24.12 \pm 1.56^{*}$ & $26.55 \pm 1.70 *$ \\
\hline $\begin{array}{l}\text { Diabetes and ischemia-reperfusion } 20 \\
\mathrm{~min} / 1 \text { hour }\end{array}$ & $47.22 \pm 2.79$ & $24.14 \pm 1.72$ & $23.07 \pm 1.10$ \\
\hline $\begin{array}{l}\text { Diabetes and ischemia-reperfusion } 12 \\
\text { days }\end{array}$ & $42.96 \pm 1.94 \#$ & $24.75 \pm 1.36$ & $18.21 \pm 1.06 \# \&$ \\
\hline
\end{tabular}


In rats with DM there were the higher levels of TFA and EFA in CFL, and TFA, NFA, and EFA in the COL, than in animals without this pathology. In the early ischemicreperfusion period, no reliable changes in fibrinolytic activity in the cortex of both lobes were detected, however, at the $12^{\text {th }}$ day of observation, there was a significant decrease of TFA, NFA and EFA in CFL and TFA and EFA in the COL both in relation to indices in diabetic rats, uncomplicated by ischemia-reperfusion of the brain, and in relation to the early post-ischemic period.

Table 4

Effect of ischemia-reperfusion onto proteolysis indices in different fields of hippocampus of male rats in conditions of diabetes mellitus $(M \pm m, n=11)$

\begin{tabular}{|c|c|c|c|}
\hline Observation group & $\begin{array}{c}\text { Lysis of low } \\
\text { molecular weight } \\
\text { proteins }(\mu \mathrm{g} \\
\text { azoalbumin/g } \\
\text { tissue per hour) }\end{array}$ & $\begin{array}{l}\text { Lysis of high } \\
\text { molecular } \\
\text { weight proteins } \\
\text { ( } \mu \text { g azocasein/g } \\
\text { tissue per hour) }\end{array}$ & $\begin{array}{c}\text { Lysis of } \\
\text { collagen }(\mu \mathrm{g} \\
\text { azocoll/g tissue } \\
\text { per hour })\end{array}$ \\
\hline \multicolumn{4}{|c|}{ Field of hippocampus CA1 } \\
\hline \multicolumn{4}{|l|}{ Control } \\
\hline Ischemia-reperfusion, $20 \mathrm{~min} / 1$ hour & $50.01 \pm 0.92$ & $24.80 \pm 0.61$ & $25.21 \pm 0.59$ \\
\hline Ischemia-reperfusion 12 days & $50.85 \pm 0.84$ & $23.98 \pm 1.09$ & $26.87 \pm 0.27 *$ \\
\hline Diabetes & $56.92 \pm 0.77^{*}$ & $27.74 \pm 1.09^{* \wedge}$ & $29.18 \pm 0.31^{* \wedge}$ \\
\hline Diabetes and ischemia-reperfusion 20 & $62.14 \pm 2.97 *$ & $27.22 \pm 1.89$ & $34.92 \pm 2.11 *$ \\
\hline $\min / 1$ hour & $58.42 \pm 2.94$ & $28.73 \pm 1.44$ & $29.69 \pm 1.94$ \\
\hline $\begin{array}{l}\text { Diabetes and ischemia-reperfusion } 12 \\
\text { days }\end{array}$ & $52.87 \pm 2.35 \#$ & $31.69 \pm 1.08$ & $21.18 \pm 2.04 \# \&$ \\
\hline \multicolumn{4}{|c|}{ Field of hippocampus CA2 } \\
\hline Control & & & \\
\hline Ischemia-reperfusion, $20 \mathrm{~min} / 1$ hour & $50.74 \pm 0.96$ & $24.72 \pm 0.81$ & $26.02 \pm 0.93$ \\
\hline Ischemia-reperfusion 12 days & $61.32 \pm 1.42 *$ & $28.95 \pm 1.09 *$ & $32.37 \pm 0.84^{*}$ \\
\hline Diab & $58.18 \pm 0.82 *$ & $24.00 \pm 0.89^{\wedge}$ & $34.18 \pm 0.63^{*}$ \\
\hline Diabetes and ischemia-reperfusion 20 & $72.09 \pm 2.94 *$ & $34.18 \pm 1.38 *$ & $37.91 \pm 1.84 *$ \\
\hline $\min / 1$ hour & $68.22 \pm 4.01$ & $40.29 \pm 2.18$ & $27.93 \pm 2.69 \#$ \\
\hline $\begin{array}{c}\text { Diabetes and ischemia-reperfusion } 12 \\
\text { days }\end{array}$ & $46.32 \pm 2.02 \# \&$ & $25.24 \pm 1.98 \# \&$ & $21.08 \pm 1.38 \# \&$ \\
\hline \multicolumn{4}{|c|}{ Field of hippocampus CA3 } \\
\hline Cont & & & \\
\hline Ischemia-reperfusion & $50.17 \pm 1.44$ & $23.80 \pm 0.68$ & $26.37 \pm 0.91$ \\
\hline Ischemia-reperfusion 12 days & $50.89 \pm 1.43$ & $24.49 \pm 0.36$ & $26.73 \pm 1.48$ \\
\hline Diabetes & $61.35 \pm 1.65^{* \wedge}$ & $28.67 \pm 0.41^{* \wedge}$ & $32.68 \pm 1.51^{* \wedge}$ \\
\hline Diabetes and ischemia-reperfusion 20 & $69.50 \pm 3.06^{*}$ & $33.71 \pm 2.29 *$ & $37.23 \pm 2.08 *$ \\
\hline $\mathrm{min} / 1$ hour & $59.49 \pm 3.07 \#$ & $31.06 \pm 1.37$ & $31.12 \pm 1.52 \#$ \\
\hline $\begin{array}{c}\text { Diabetes and ischemia-reperfusion } 12 \\
\text { days }\end{array}$ & $48.18 \pm 2.16 \# \&$ & $25.02 \pm 1.68 \# \&$ & $23.16 \pm 1.43 \# \&$ \\
\hline
\end{tabular}


According to the results represented in table 4 , in nondiabetic rats, the reaction to the 20-minute ischemia with one-hour reperfusion in the field of the hippocampus CA1 was to significant increase in the activity of EFA, in the field CA2 - in the growth of all the studied parameters, and in the field CA3 during this period no reliable changes were detected. During the $12^{\text {th }}$ day of ischemic-reperfusion period, in the fields CA1 and CA3, the growth of TFA, NFA and EFA; and in the field CA2 - TFA and EFA both on the control and in comparison with the values of these indicators in the early observation period was revealed.

In rats with diabetes there were the higher levels of TFA and EFA in the field CA1; TFA, NFA and EFA - in the fields CA2 and CA3 than in animals without it. According to some authors, violated fibrinolytic activity in diabetes is a risk factor for stroke, and its normalization is a means of this complication prevention [6, 13]. After 20-minute ischemia with one-hour reperfusion, in the rats with DM in the field CA1 there were no reliable changes in the investigated parameters of tissue fibrinolysis, in the field CA2 there was a decrease of EFA, in the field CA3 - there was a decrease of TFA and EFA. At the 12th day of the post-ischemic period in comparison with the indicators in diabetes without ischemia of the brain in the field CA1 there was a decrease of TFA and EFA, in the fields CA2 and CA3 - of TFA, NFA and EFA. In addition, in this period, as for the early post-ischemic period in the field CA1, there was a lower activity of the EFA, in the fields CA2 and CA3 - of all of the studied parameters of fibrinolytic activity.

Consequently, the general tendency in the response of fibrinolytic activity to the ischemia-reperfusion of the brain in DM is its inhibition.

Conclusions. In the studied brain structures during both time intervals, the DM eliminates the reaction of low- and high molecular weight proteins to the ischemiareperfusion and suppresses fibrinolytic activity.

\section{References}

1. Skibo G.G. Ispolzovanie razlichnikh eksperimentalnikh modelei dlia izucheniia kletochnikh mechanizmov ishemicheskogo porazheniia mozga. Patologija. 2004; 1(1): 22-30.

2. Mahalyas VM, Mikhyeyev AO, Rohovyy YuYe. Suchasni metody eksperymental'nykh ta klinichnykh doslidzhen' tsentral'noyi naukovo-doslidnoyi laboratoriyi Bukovyns'koyi derzhavnoyi medychnoyi akademiyi. Chernivtsi; 2001. 42 s. 
3. Tkachuk OV. Influence of streptozotocin-induced diabetes and incomplete global ischemia of the brain onto apoptosis in thymus of rats. Fiziolohichny zhurnal. 2011; 57(6): $58-64$.

4. Hu J, Klein JD, Du J, Wang XH. Cardiac Muscle Protein Catabolism in Diabetes Mellitus: Activation of the Ubiquitin-Proteasome System by Insulin Deficiency. Endocrinology. 2008; 149(11): 5384-5390. DOI: https://doi.org/10.1210/en.2008-0132 [PMid:18653708 PMCid:PMC2734490]

5. Nagai R, Murray DB, Metz TO. Chelation: a fundamental mechanism of action of AGE inhibitors, AGE breakers, and other inhibitors of diabetes complications. Diabetes. 2012; 61(3): 549-559. DOI: https://doi.org/10.2337/db11-1120 [PMid:22354928 PMCid:PMC3282805]

6. Jotic A, Milicic T, Covickovic Sternic N, Kostic VS et al. Decreased Insulin Sensitivity and Impaired Fibrinolytic Activity in Type 2 Diabetes Patients and Nondiabetics with Ischemic Stroke. Int. J. Endocrinol. 2015; 2015: 934791.

7. Curcio M, Leal G, Salazar I L et al. Excitotoxic stimulation downregulates the ubiquitin-proteasome system through activation of NMDA receptors in cultured hippocampal neurons. Biochimica et Biophysica Acta (BBA) - Molecular Basis of Disease. 2013; 1832(1): 263-274. DOI: https://doi.org/10. 1016/j.bbadis.2012.10.009 [PMid:23069389]

8. Fierabracci A. The putative role of proteolytic pathways in the pathogenesis of Type 1 diabetes mellitus: The 'autophagy' hypothesis. Medical Hypotheses. 2014; 82(5): 553-557. DOI: https://doi.org/10. 1016/j.mehy.2014.02.010 [PMid:24582332]

9. Genomic approach to selective vulnerability of the hippocampus in brain ischemiahypoxia. Schmidt-Kastner R. Neuroscience. 2015; 309: 259-279. DOI: https://doi.org/10.1016/j. neuroscience.2015.08.034 [PMid:26383255]

10. Goldberg RB. Cytokine and cytokine-like inflammation markers, endothelial dysfunction, and imbalanced coagulation in development of diabetes and its complications. J. Clin. Endocrinol. Metab. 2009; 94(9): 3171-3182. DOI: https://doi.org/10.1210/jc.2008-2534 [PMid:19509100]

11. Queisser MA, Yao D, Geisler S et al. Hyperglycemia Impairs Proteasome Function by Methylglyoxal. Diabetes. 2010; 59(3): 670-678. DOI: https://doi.org/10.2337/db08-1565 [PMid:20009088 PMCid:PMC2828656]

12. Bandeira $\mathrm{S}$ de $\mathrm{M}$, Fonseca LJ $\mathrm{S}$ da, Guedes $\mathrm{G}$ da $\mathrm{S}$ et al. Oxidative Stress as an Underlying Contributor in the Development of Chronic Complications in Diabetes Mellitus. 
Int. J. Mol. Sci. 2013; 14(2): 3265-3284. DOI: https://doi.org/10.3390/ijms14023265 [PMid:23385234 PMCid:PMC3588043]

13. Tjarnlund-Wolf A, Brogren H, Lo EH, Wang X. Plasminogen Activator Inhibitor1 and Thrombotic Cerebrovascular Diseases. Stroke. 2012; 43(10): 2833-2839. DOI: https://doi.org/10.1161/STROKEAHA. 111.622217 [PMid:22879095 PMCid:PMC3712849]

14. Hernandes MS, Lassegue B, Hilenski LL et al. Polymerase delta-interacting protein 2 deficiency protects against blood-brain barrier permeability in the ischemic brain. $\mathrm{J}$. Neuroinflammation. 2018; 15(1):45. DOI: https: //doi.org/10.1186/s12974-017-1032-1 [PMid:29452577 PMCid:PMC5816395]

15. Kong L, Wang Y, Luo M et al. Prevention of Streptozotocin-Induced Diabetic Nephropathy by MG132: Possible Roles of Nrf2 and I?B. Oxid. Med. Cell. Longev. 2017; 2017: 3671751.

16. Sneha BB, Ashok DC, Rakesh SJ et al. Proteomic Analysis of Protease Resistant Proteins in the Diabetic Rat Kidney. Mol. Cell. Proteomics. 2013; 12(1): 228-236. DOI: https://doi.org/10.1074/mcp.M112.020651 [PMid:23118466 PMCid:PMC3536903]

17. Ramasamy R, Yan SF, Schmidt AM. Receptor for AGE (RAGE): signaling mechanisms in the pathogenesis of diabetes and its complications. Ann. N. Y. Acad. Sci. 2011; 1243: 88-102. DOI: https://doi.org/10.1111/j.1749-6632.2011.06320.x [PMid:22211895PMCid:PMC4501013]

18. Sherwood NM, Timiras PS. A stereotaxis atlas of the developing rat brain. Berkely-Los Angeles-London: University of California Press. 1970; 208. 